\title{
Letter to the Editor: Antenatal steroids and their administration time for preventing morbidity in preterm labor
}

\author{
Talat Umut Kutlu Dilek', Elif Ganime Aydeniz ${ }^{2}$ \\ ${ }^{\prime}$ Department of Obstetrics and Gynecology, Faculty of Medicine, Acıbadem Mehmet Ali Aydinlar University, Istanbul, Turkey \\ ${ }^{2}$ Center of Assisted Reproductive Technologies, Acıbadem Mebmet Ali Aydinlar University Atakent Hospital, Istanbul, Turkey
}

\section{Dear Editor,}

Preterm labor is the most significant reason of perinatal mortality in the world. Although the major reason for morbidity and mortality in preterm fetuses is respiratory distress of the newborn, short-term outcomes such as necrotising enterocolitis, intraventricular hemorrhage, newborn retinopathy and patent ductus arteriosus and long-term outcomes such as cerebral palsy, bronchopulmonary dysplasia and short bowel syndrome also should be considered. While prevention of preterm labor is the major action to prevent these problems, different pharmacological treatments should also be taken into account in cases where preterm labor cannot be prevented. In the last four decades, corticosteroids provided a significant decrease in the neonatal mortality and morbidity rates. In 1994, NICHD (National Institute of Child Health and Development) recommended using them to prevent prematurityrelated respiratory distress in preterm labors. ${ }^{[1]}$ It has been reported that antenatal steroids also decrease the rates of newborn mortality, intraventricular hemorrhage and necrotising enterocolitis. In this regard, the use of antenatal steroid between 24 and 34 weeks of gestation in pregnant women with high risk of preterm labor has been recommended, and this recommendation has also been supported by ACOG. Current antenatal steroid administration is conducted by two different protocols, and dexamethasone and betamethasone are used for this purpose. ${ }^{[2]}$ The effects of two different molecules on lung maturation and intraventricular hemorrhage rate are similar. While dexamethasone is a molecule which is cheap and easy to obtain, the binding rate of betamethasone to albumin is lower and this increases the transplacental transition rate.

Optimal efficacy of antenatal steroids starts 24 hours after the last administration and continues for 7 days, and it starts to wear off afterwards. Therefore, in cases where preterm labor does not occur, a repeat or rescue dose should be administered when same problem is faced again in the future. Steroid administrations in repeat doses suppress maternal hypothalamichypophyseal axis, disrupt glycemic control in diabetic pregnant women by leading hyperglycemia, and may cause lung edema by its concomitant use with betamimetics in particular. In terms of newborn, hypoglycemia and hyperbilirubinemia are the major problems. As long-term and repeat doses of antenatal steroids may cause cerebral atrophy, microcephaly and low birth weight in fetus, administrating repeat doses is not recommended. ${ }^{[3]}$

It was shown in a meta-analysis ${ }^{[4]}$ evaluated 30 studies and published in Cochrane database that steroids decreased the rates of perinatal mortality (RR: 0.72), neonatal death (RR: 0.69), respiratory distress syndrome (RR: 0.66), intraventricular hemorrhage (RR:
Correspondence: Talat Umut Kutlu Dilek, MD. Department of Obst. \& Gyn., Faculty of Medicine, Acıbadem MAA University, Istanbul, Turkey. e-mail: umutdilek@gmail.com Received: October 31, 2018; Accepted: December 15, 2018

Please cite this article as: Dilek TUK, Aydeniz EG. Letter to the Editor: Antenatal steroids and their administration time for preventing morbidity in preterm labor. Perinatal Journal 2018;26(3):167-169.

(C)2018 Perinatal Medicine Foundation
Available online at: www.perinataljournal.com/20180263007 doi: $10.2399 /$ prn.18.0263007 QR (Quick Response) Code:

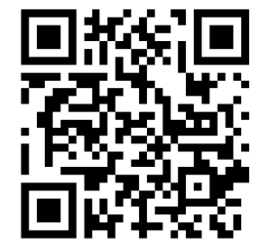


Table 1. Administration scheme of antenatal steroid.

\begin{tabular}{|c|c|c|c|c|c|c|}
\hline Guidelines & $\begin{array}{l}\text { Administration } \\
\text { week }\end{array}$ & Protocol & $\begin{array}{l}\text { 34-37. weeks } \\
\text { of gestation }\end{array}$ & $\begin{array}{l}22 \text { weeks - } 23 \text { weeks } \\
\text { and } 6 \text { days of gestation }\end{array}$ & $\begin{array}{l}\text { Repeat dose } \\
\text { administration }\end{array}$ & $\begin{array}{l}\text { Premature rupture } \\
\text { of membrane }\end{array}$ \\
\hline ACOG (2017) & $\begin{array}{l}\text { 24-34 weeks } \\
\text { of gestation }\end{array}$ & $\begin{array}{l}\text { Dexamethasone } 6 \mathrm{mg} \text { - a } \\
\text { total of } 4 \text { administrations } \\
\text { every } 12 \text { hours or } \\
\text { betamethasone } 12 \mathrm{mg} \text { - } \\
2 \text { administrations } \\
\text { every } 24 \text { hours }\end{array}$ & $\begin{array}{l}\text { It can be } \\
\text { administrated }\end{array}$ & $\begin{array}{l}\text { It can be administered } \\
\text { after } 23 \text { weeks of } \\
\text { gestation }\end{array}$ & $\begin{array}{l}\text { If the time elapsed } \\
\text { after the last dose is } \\
14 \text { days and more }\end{array}$ & Indicated \\
\hline SOGC (2018) & $\begin{array}{l}24 \text { weeks - } \\
34 \text { weeks and } \\
6 \text { days of } \\
\text { gestation }\end{array}$ & $\begin{array}{l}\text { Dexamethasone } 6 \mathrm{mg} \text { - a } \\
\text { total of } 4 \text { administrations } \\
\text { every } 12 \text { hours or } \\
\text { betamethasone } 12 \mathrm{mg} \text { - } \\
2 \text { administrations } \\
\text { every } 24 \text { hours }\end{array}$ & Controversial & Controversial & $\begin{array}{l}\text { If the time elapsed } \\
\text { after the last dose is } \\
14 \text { days and more }\end{array}$ & Indicated \\
\hline NICE (2015) & $\begin{array}{c}26 \text { weeks - } \\
33 \text { weeks and } \\
6 \text { days of } \\
\text { gestation }\end{array}$ & $\begin{array}{l}\text { Dexamethasone } 6 \mathrm{mg} \text { - a } \\
\text { a total of } 4 \text { administrations } \\
\text { every } 12 \text { hours or } \\
\text { betamethasone } 12 \mathrm{mg} \text { - } \\
2 \text { administrations } \\
\text { every } 24 \text { hours }\end{array}$ & $\begin{array}{l}\text { It can be administered } \\
\text { between } 34 \text { weeks } \\
\text { and } 35 \text { weeks and } \\
6 \text { days of gestation }\end{array}$ & $\begin{array}{l}\text { Discuss with the family } \\
\text { between } 22 \text { weeks and } 23 \\
\text { weeks and } 6 \text { days of gestation; } \\
\text { consider between } 24 \\
\text { weeks } 25 \text { weeks and } \\
6 \text { days of gestation }\end{array}$ & ; & Indicated \\
\hline $\begin{array}{l}\text { Turkish } \\
\text { Ministry of } \\
\text { Health } \\
\text { (2014) }\end{array}$ & $\begin{array}{l}24-34 \text { weeks } \\
\text { of gestation }\end{array}$ & $\begin{array}{l}\text { Dexamethasone } 6 \mathrm{mg} \text { - } \\
\text { a total of } 4 \text { administrations } \\
\text { every } 12 \text { hours or } \\
\text { betamethasone } 12 \mathrm{mg} \text { - } \\
2 \text { administrations } \\
\text { every } 24 \text { hours }\end{array}$ & $\begin{array}{l}\text { By the decision } \\
\text { of obstetrician }\end{array}$ & $\begin{array}{l}\text { By the decision } \\
\text { of obstetrician }\end{array}$ & $\begin{array}{l}\text { By the decision } \\
\text { of obstetrician }\end{array}$ & $\begin{array}{l}\text { Single dose before } \\
32 \text { weeks of } \\
\text { gestation, by doctor } \\
\text { decision between } 32 \\
\text { and } 34 \text { weeks of } \\
\text { gestation }\end{array}$ \\
\hline
\end{tabular}

ACOG: American College of Obstetrics and Gynecology; NICE: National Institute of Health Care Excellence; SOGC: Society of Obstetricians and Gynaecologists of Canada.

$0.55)$, necrotising enterocolitis (RR: 0.5 ), and the need for ventilator support (RR: 0.6).

Although the use of antenatal corticosteroids before 24 weeks of gestation is controversial, the lower limit can be 22-23 weeks of gestation since the outcomes of newborn intense care get better in the extreme premature group with very low birth weight. While this group decreases the mortality rates in newborns, it does not affect morbidity rates. ${ }^{[5]}$

Chorioamnionitis and multiple pregnancies are not contraindicated for the use of antenatal steroid, and its administration scheme is similar to singleton pregnancies. While the administration threshold for antenatal steroids was 34 weeks of gestation until two years ago, it was shown in a randomized controlled study which was supported NIH that extending administration time up to 37 weeks of gestation led to a decrease in newborn respiratory distress. ${ }^{[6]}$ Therefore, ACOG updated its guidelines in August 2017 and extended the upper limit for administration up to 37 weeks of gestation. In the same guidelines, rescue treatment is recommended for pregnant women below 34 weeks of gestation who were previously administered corticosteroid in cases where the time elapsed since the last dose is longer than 14 days and where preterm labor condition arises and becomes inevitable in the next 7 days. ${ }^{[7]}$

In conclusion, antenatal steroids should be administered in order to decrease neonatal morbidity and mortality in singleton and multiple pregnancies where preterm labor is inevitable between 24 and 34 weeks of gestation. The lower limit can be as low as 22 weeks of gestation depending on the newborn intense care capabilities, and the upper limit can be extended up to 37 weeks of gestation according to the recent literature data. The mode of administration is same in singleton and multiple pregnancies. It should be remembered that its effects start within 24 hours after the last dose and continue for 7 days, and routine repeat doses should be avoided (Table 1). Since almost 2/3 of the preterm labor cases still do not result with preterm labor 1 week later, repeat doses should be referred only in cases where preterm labor is inevitable considering the fetal-neonatal and maternal adverse effects. ${ }^{[8,9]}$

Conflicts of Interest: No conflicts declared. 


\section{References}

1. Effects of antenatal steroids for fetal maturation on perinatal outcomes. NIH Consensus Development Panel on the Effect of Corticosteroids for Fetal Maturation on Perinatal Outcomes. JAMA 1995;273:413-8.

2. Skoll A, Boutin A, Bujold E, Burrows J, Crane J, Geary M, et al. No. 364-Antenatal corticosteroid therapy for improving neonatal outcomes. J Obstet Gynaecol Can 2018;40:1219-39.

3. Wapner RJ, Gyamfi-Bannerman C, Thom EA; Eunice Kennedy Shriver National Institute of Child Health and Human Development Maternal-Fetal Medicine Units Network. What we have learned about antenatal corticosteroid regimen. Semin Perinatol 2016;40:291-7.

4. Roberts D, Brown J, Medley N, Dalziel SR. Antenatal corticosteroids for accelerating fetal lung maturation for women at risk of preterm birth. Cochrane Database Syst Rev 2017; 3:CD004454.

5. Magann EF, Haram K, Ounpraseuth S, Mortensen J, Spencer HJ, Morrison JC. Use of antenatal corticosteroids in special circumstances: a comprehensive review. Acta Obstet Gynecol Scand 2017;96:395-430.

6. Bannerman-Gyamfi C, Thom EA, Blackwell SC, Tita ATN, Reddy UM, Saade GR, et al.; NICHD Maternal-Fetal Medicine Units Network. Antenatal betamethasone for women at risk for late preterm delivery. N Engl J Med 2016; 374:1311-20.

7. Committee on Obstetric Practice. Committee Opinion No. 713: Antenatal corticosteroid therapy for fetal maturation. Obstet Gynecol 2017;130:e102-9.

8. TC. Sağlık Bakanlı̆̆ı Türkiye Halk Sağlı̆̆ı Kurumu [Internet]. Antenatal steroid uygulaması [cited 2017 Apr 17]. Available from: https://khgmsaglikhizmetleridb.saglik.gov.tr/TR,42838/ antenatal-steroid-uygulamasi.html

9. Boutin A, Skoll A, Bujold E, Burrows J, Crane J, Geary M, et al. Antenatal corticosteroid therapy for improving neonatal outcomes: balancing benefits and risks. J Obstet Gynaecol Can 2018;40:11193-97. 